\title{
Gas, Oil, and Water Production from Jonah, Pinedale, Greater Wamsutter, and Stagecoach Draw Fields in the Greater Green River Basin, Wyoming
}

By Philip H. Nelson, Shauna M. Ewald, Stephen L. Santus, and Patrick K. Trainor

Open-File Report 2009-1290 


\title{
U.S. Department of the Interior \\ KEN SALAZAR, Secretary \\ U.S. Geological Survey \\ Marcia K. McNutt, Director
}

\section{U.S. Geological Survey, Reston, Virginia: 2010}

\author{
About USGS Products \\ For product and ordering information: \\ World Wide Web: http://www.usgs.gov/pubprod \\ Telephone: 1-888-ASK-USGS \\ For more information on the USGS - the Federal source for science about the Earth, its natural and \\ living resources, natural hazards, and the environment: \\ World Wide Web: http://www.usgs.gov \\ Telephone: 1-888-ASK-USGS
}

\section{About this Product}

Publishing support provided by:

Denver Publishing Service Center, Denver, Colorado

For more information concerning this publication, contact:

Team Chief Scientist, USGS Central Region Energy Resources Team

Box 25046, Mail Stop 980

Denver Federal Center

Denver, C0 80225-0046

(303) 236-1735

Or visit the Central Region Energy Resources Team Web site at:

http://energy.usgs.gov

Suggested citation:

Nelson, P.H., Ewald, S. M., Santus, S.L., and Trainor, P.K., 2010, Gas, oil, and water production from Jonah, Pinedale, Greater Wamsutter, and Stagecoach Draw fields in the Greater Green River Basin, Wyoming: U.S. Geological Survey Open-File Report 2009-1290, 5 plates, pamphlet $19 \mathrm{p}$.

Any use of trade, product, or firm names is for descriptive purposes only and does not imply endorsement by the U.S. Government.

Although this report is in the public domain, permission must be secured from the individual copyright owners to reproduce any copyrighted materials contained within this report. 


\section{Contents}

Abstract
Introduction
Jonah Field
Pinedale Field
Greater Wamsutter Field
Stagecoach Draw
Summary
Acknowledgments
References Cited

\section{Figures}

1. Map of Greater Green River Basin showing location of four gas fields ..............................2

2. Generalized correlation chart for Upper Cretaceous and lower Tertiary strata in the

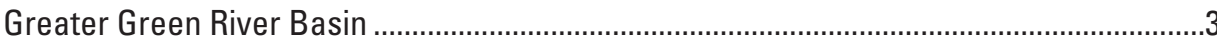

3. Example plot of fluid production versus time with corresponding bi-logarithmic

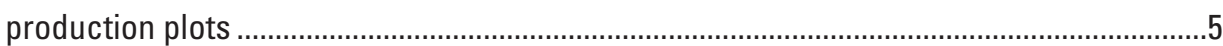

4. Example plot of fluid production versus time with vector plots of changes in

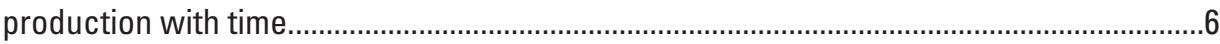

5. Oil and gas types plotted on a log-log diagram of oil and gas production rates.................8

6. Demonstration of the difference between a plot with logarithmic scales $(A)$ and a plot with linear scales $(B)$, using water and gas production data as an example..............9

7. Location of gas fields and wells producing gas and oil from the Almond Formation, eastern part of Greater Green River Basin.......................................................................12

8. Production plots from three wells in the Almond Formation ..............................................14

9. Plots of first-sample water against gas production rates for six areas within the Greater Wamsutter field . .17

10. Water and gas production rates displayed as vector plots for the Almond Formation for all wells in the Greater Wamsutter field

\section{Tables}

1. Estimates of water released at surface

\section{Plates}

1. Gas, oil, and water production from Jonah field........................................................ Online

2. Gas, oil, and water production from Pinedale field ................................................... Online

3. Gas, oil, and water production by area in the Greater Wamsutter field ..................... Online

4. Gas, oil, and water production by formation unit in the Greater Wamsutter field ..... Online

5. Gas, oil, and water production from Stagecoach Draw field .................................... Online 


\section{Appendices}

1. Spreadsheet with well locations and data for Jonah field ........................................... Online

2. Spreadsheet with well locations and data for Pinedale field ...................................... Online

3. Spreadsheet with well locations and data for Greater Wamsutter field..................... Online

4. Spreadsheet with well locations and data for Stagecoach Draw field ...................... Online

\section{Conversion Factors}

\begin{tabular}{|c|c|c|}
\hline Multiply & By & To obtain \\
\hline \multicolumn{3}{|c|}{ LENGTH } \\
\hline foot $(\mathrm{ft})$ & 0.3048 & meter $(\mathrm{m})$ \\
\hline mile (mi) & 1.609 & kilometer $(\mathrm{km})$ \\
\hline \multicolumn{3}{|c|}{ VOLUME } \\
\hline $\begin{array}{l}\text { barrel (bbl), (petroleum, } \\
1 \text { barrel=42 gal) }\end{array}$ & 0.1590 & cubic meter $\left(\mathrm{m}^{3}\right)$ \\
\hline cubic foot $\left(\mathrm{ft}^{3}\right)$ & 0.02832 & cubic meter $\left(\mathrm{m}^{3}\right)$ \\
\hline \multicolumn{3}{|c|}{ FLOW RATE } \\
\hline cubic foot per day $\left(\mathrm{ft}^{3} / \mathrm{d}\right)$ & 0.02832 & cubic meter per day $\left(\mathrm{m}^{3} / \mathrm{d}\right)$ \\
\hline \multicolumn{3}{|c|}{ PRESSURE } \\
\hline atmosphere, standard (atm) & 101.3 & kilopascal (kPa) \\
\hline bar & 100 & kilopascal (kPa) \\
\hline pound per square inch $\left(\mathrm{lb} / \mathrm{in}^{2}\right)$ & 6.895 & kilopascal (kPa) \\
\hline \multicolumn{3}{|c|}{ DENSITY } \\
\hline pound per cubic foot $\left(\mathrm{lb} / \mathrm{ft}^{3}\right)$ & 16.02 & $\begin{array}{l}\text { kilogram per cubic meter } \\
\left(\mathrm{kg} / \mathrm{m}^{3}\right)\end{array}$ \\
\hline pound per cubic foot $\left(\mathrm{lb} / \mathrm{ft}^{3}\right)$ & 0.01602 & $\begin{array}{l}\text { gram per cubic centimeter } \\
\left(\mathrm{g} / \mathrm{cm}^{3}\right)\end{array}$ \\
\hline
\end{tabular}




\title{
Gas, Oil, and Water Production from Jonah, Pinedale, Greater Wamsutter, and Stagecoach Draw Fields in the Greater Green River Basin, Wyoming
}

\author{
By Philip H. Nelson, ${ }^{1}$ Shauna M. Ewald, ${ }^{2}$ Stephen L. Santus, ${ }^{2}$ and Patrick K. Trainor ${ }^{3}$
}

\section{Abstract}

Gas, oil, and water production data were compiled from selected wells in four gas fields in rocks of Late Cretaceous age in southwestern Wyoming. This study is one of a series of reports examining fluid production from tight-gas reservoirs, which are characterized by low permeability, low porosity, and the presence of clay minerals in pore space. Production from each well is represented by two samples spaced five years apart, the first sample typically taken two years after commencement of production. For each producing interval, summary diagrams of oil versus gas and water versus gas production show fluid production rates, the change in rates during five years, the water-gas and oil-gas ratios, and the fluid type. These diagrams permit well-to-well and field-to-field comparisons. Fields producing water at low rates (water dissolved in gas in the reservoir) can be distinguished from fields producing water at moderate or high rates, and the water-gas ratios are quantified.

The ranges of first-sample gas rates in Pinedale field and Jonah field are quite similar, and the average gas production rate for the second sample, taken five years later, is about one-half that of the first sample for both fields. Water rates are generally substantially higher in Pinedale than in Jonah, and water-gas ratios in Pinedale are roughly a factor of ten greater in Pinedale than in Jonah. Gas and water production rates from each field are fairly well grouped, indicating that Pinedale and Jonah fields are fairly cohesive gas-water systems. Pinedale field appears to be remarkably uniform in its flow behavior with time. Jonah field, which is internally faulted, exhibits a small spread in first-sample production rates. In the Greater Wamsutter field, gas production from the upper part of the Almond Formation is greater than from the main part of the Almond. Some wells in the main and the combined (upper and main parts) Almond show increases in water production

\footnotetext{
${ }^{1}$ U.S. Geological Survey, Denver, Colo.

${ }^{2}$ Metropolitan State College, Denver, Colo.

${ }^{3}$ Colorado School of Mines, Golden, Colo.
}

with time, whereas increases in water production are rare in the upper part of the Almond, and a higher percentage of wells in the upper part of the Almond show water decreasing at the same rate as gas than in the main or combined parts of the Almond.

In Stagecoach Draw field, the gas production rate after five years is about one-fourth that of the first sample, whereas in Pinedale, Jonah, and Greater Wamsutter fields, the production rate after five years is about one-half that of the first sample. The more rapid gas decline rate seems to be the outstanding feature distinguishing Stagecoach Draw field, which is characterized as a conventional field, from Pinedale, Jonah, and Greater Wamsutter fields, which are generally characterized as tight-gas accumulations. Oil-gas ratios are fairly consistent within Jonah, Pinedale, and Stagecoach Draw fields, suggesting similar chemical composition and pressuretemperature conditions within each field, and are less than the $20 \mathrm{bbl} / \mathrm{mmcf}$ upper limit for wet gas. However, oil-gas ratios vary considerably from one area to another in the Greater Wamsutter field, demonstrating a lack of commonality in either chemistry or pressure-temperature conditions among the six areas.

In all wells in all four fields examined here, water production commences with gas production - there are no examples of wells with water-free production and no examples where water production commences after first-sample gas production. The fraction of records with water production higher in the second sample than in the first sample varies from field to field, with Pinedale field showing the lowest percentage of such cases and Jonah field showing the most. Most wells have water-gas ratios exceeding the amount that could exist dissolved in gas at reservoir pressure and temperature.

\section{Introduction}

Tight-gas sandstones now contribute a significant proportion of gas production in the United States. Despite this success, many questions remain concerning the nature of fluids in 
tight-gas (low permeability) systems. This study is part of an ongoing effort to examine the early production from a number of tight-gas systems in the Rocky Mountain region of the United States (Nelson and others, 2009; Nelson and Hoffman, 2009). Early production, rather than cumulative production, is examined in order to gain a record of fluid flow unperturbed by well interference and pressure reduction. By conducting a systematic study of a number of tight-gas systems, we hope to gain insight into the fluid-flow characteristics of reservoirs and ultimately relate those characteristics to the geological setting and hydrocarbon-charging scenario. The purpose of this report is to document our findings for gas, water, and oil production from four fields from the Greater Green River Basin in southwestern Wyoming (fig. 1).

Productive strata examined in the fields included in our study_Jonah, Pinedale, Greater Wamsutter, and Stagecoach Draw-are Late Cretaceous in age (fig. 2). Jonah and Pinedale fields are low porosity, sub-millidarcy permeability, and have inverted pressure profiles, that is, overpressure builds from the top of the gas system to a maximum near the

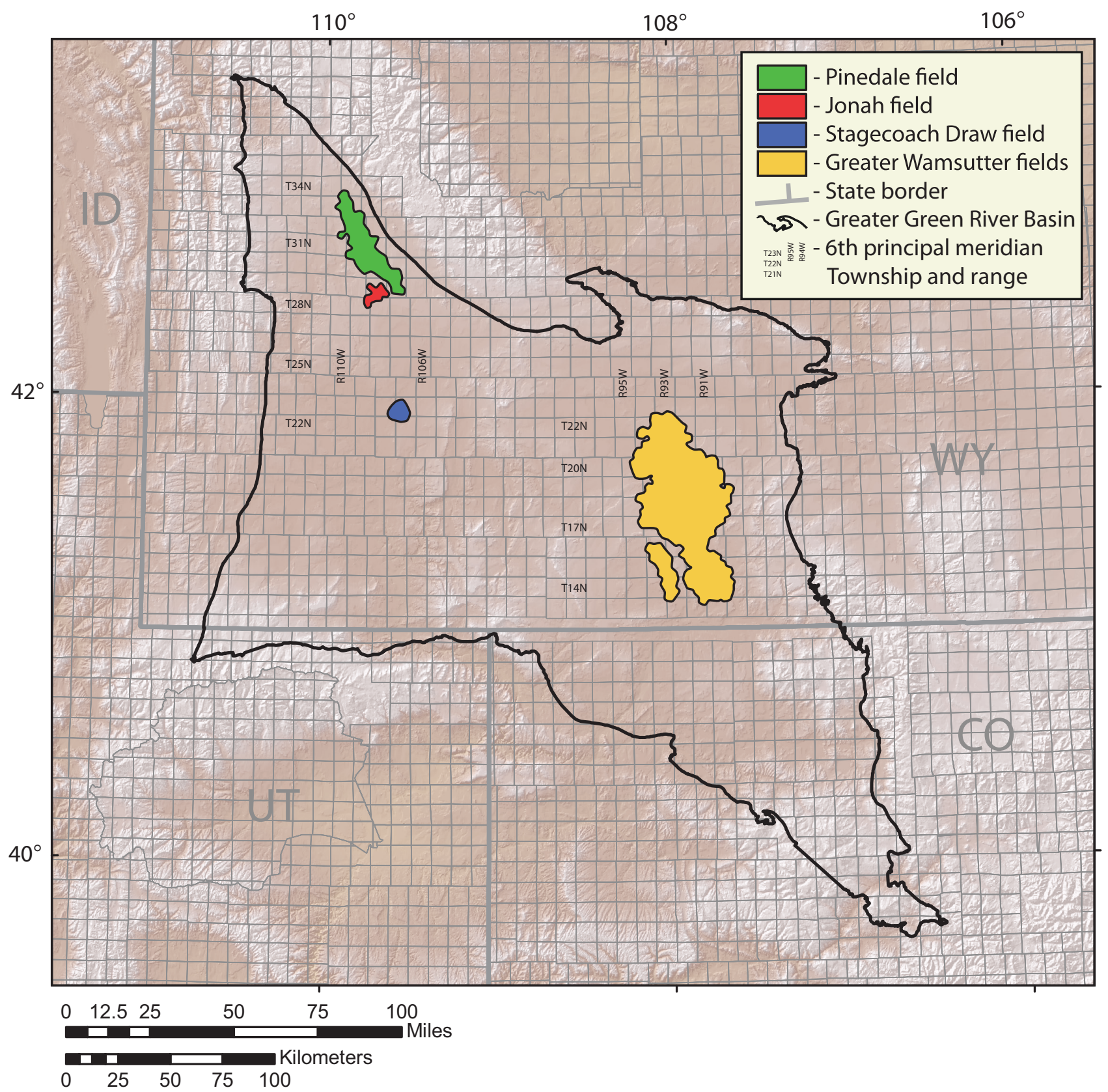

Figure 1. Map of Greater Green River Basin showing location of four gas fields. Field outlines are based on wells considered in this study. 


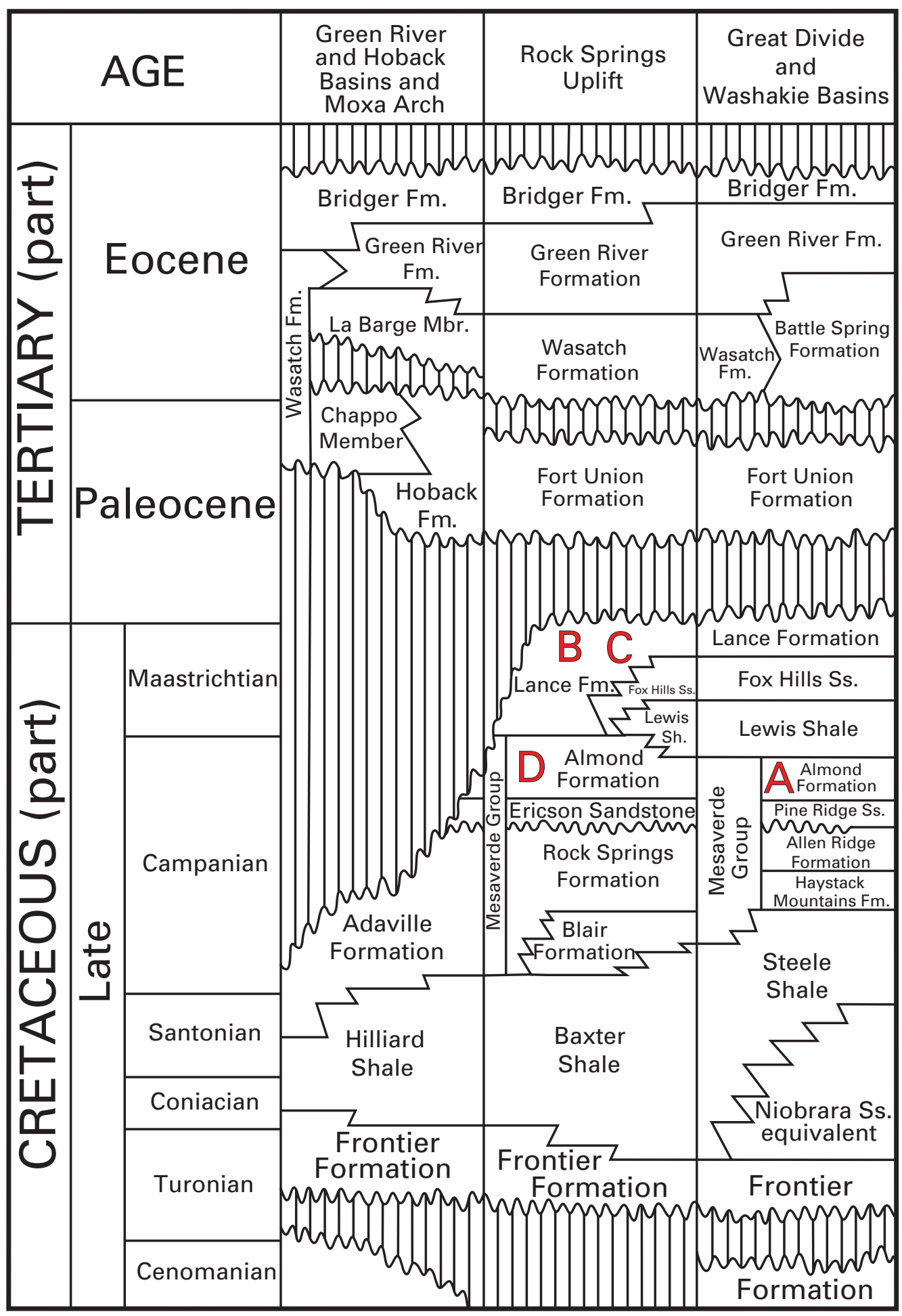

Figure 2. Generalized correlation chart for Upper Cretaceous and lower Tertiary strata in the Greater Green River Basin. Letters designate gas systems in this study: A, Greater Wamsutter; B, Jonah field; C, Pinedale field; D, Stagecoach Draw field. Modified from Johnson and others (2005).

base. These two gas systems can readily be characterized as tight-gas systems. Characterization of the gas accumulations of the Greater Wamsutter area is not as straightforward, in that the upper Almond sandstones are not uniformly of low permeability and porosity. The fourth gas system considered here, Stagecoach Draw field, has the characteristics of a conventional (buoyant) reservoir, and is included to provide a contrasting case to the tight-gas systems. In all examples, we 
Gas, Oil, and Water Production from Jonah, Pinedale, Greater Wamsutter, and Stagecoach Draw Fields, Wyoming

looked for (1) wells with early production in order to sample the fluid production when the reservoir was first tapped and to avoid well interference effects, (2) continuity of production so that production trends with time could be sampled, (3) indications that records are valid, and (4) documentation of depths of producing intervals and stimulation methods.

Daily production rates were computed by dividing monthly volumes by the number of days of production in a month. The resulting values of (1) gas rate, in thousands of cubic feet per day (mcf/d); (2) water rate, in barrels per day (bbl/d); and (3) oil rate, in barrels per day (bbl/d) are plotted on a logarithmic scale as a function of time (fig. $3 A$ ). To determine a representative flow rate of gas, oil, or water from a well, a three-month time interval was selected early in the history of a given production record for which fluid production was judged to be representative of flow. This time interval, referred to as the "first sample" in this report, is generally selected to be about two years after commencement of production; such delay serves to eliminate early transients and early changes in equipment, and reduces the likelihood that fracturing fluids are included in the water tally. Fluctuations in production rates such as those in the New Fork Unit 7-3 well are not uncommon. For the example in figure $3 A$, the production rates were averaged over the months of JuneAugust, 2003, resulting in the values posted on the figure.

The resulting average daily rates are then posted on summary plots with bi-logarithmic scales (figs. $3 B$ and $3 C$ ), which accommodate wide ranges of production rates. With the use of bi-logarithmic axes, constant ratios of production rates lie on 45-degree lines, the ratio increasing upwards and to the left. Water production of $10.1 \mathrm{bbl} /$ day and gas production of 3,485 mcf/day from well New Fork Unit 7-3 determine the location of the single point in figure $3 B$. The water:gas ratio for this well, 2.90 barrels per million cubic feet (bbl/mmcf), which is represented as a diagonal line, is the lowest of the wells examined in this study from the Pinedale field. In similar fashion, the first-sample oil rate of $18.0 \mathrm{bbl} /$ day and gas rate of 3,485 mcf/day determine the location of the point in figure $3 C$, with an oil:gas ratio of $5.2 \mathrm{bbl} / \mathrm{mmcf}$ represented by a diagonal line. Wet gases, also called condensate gases, have gas:oil ratios in excess of 50,000 scf/bbl, or oil:gas ratios of less than $20 \mathrm{bbl}$ of condensate/mmcf of gas (McCain, 1990), and occupy the lower right corner of the plot. Thus, the representative data point in figure $3 C$ lies within the wet gas field.

To show the change in gas and water production in each well, a second three-month average is computed five years after the first average (fig. 4A). The gas and water production figures from the second sample are plotted on the bi-logarithmic production plot (red circle in fig. $4 B$ ). Each secondsample value is linked to its first-sample value (blue triangle in figs. $3 B$ and $4 B$ ) by a dashed line, producing a vector that shows the amounts and the change of water and gas production over five years. On a bi-logarithmic graph, a vector of a given length and angle represents the same fractional changes in daily gas and water production regardless of where it is positioned on the graph. In the example shown in figure 4, gas production decreases from 3,485 to $1,358 \mathrm{mcf} /$ day over five years, water production decreases from 10.1 to $6.78 \mathrm{bbl} /$ day over five years, and the water:gas ratio increases from 2.9 $\mathrm{bbl} / \mathrm{mmcf}$ (fig. $3 B$ ) to $5.0 \mathrm{bbl} / \mathrm{mmcf}$ (fig. $4 B$ ) over five years.

To clarify the relative changes in water and gas production among wells, a bi-logarithmic plot of the change in water and gas production places all early-time production at a common origin (single square at 1,1 in fig. $4 C$ ) so that changes in production over a five-year span can be compared among wells. The length and orientation of each vector is the same in figures $4 B$ and $4 C$, but the origin, which is its value at the first sample, has been normalized, or translated to the center $(1,1)$ position of the plot in figure $4 C$. In this example, gas, water, and oil records were complete so a second sample could be obtained five years after the first sample, but in a few cases where data were missing, values from an earlier time (three or four years after the first sample) were extrapolated to obtain a second sample.

As some water can exist as a dissolved phase in gas within the reservoir, the question arises as to how much of the produced water was originally dissolved in the reservoir and then condensed at the surface. The amount of water dissolved in gas in reservoirs increases with increasing temperature and decreases with increasing pressure (McCain, 1990, p. 460). The amount released depends upon the pressure and temperature at the surface; a fixed value of $33 \mathrm{lb} / \mathrm{mmcf}$ was assumed, based on considerations by McCain (1990). Our computations, based upon the approach given by McCain (1990, p. 460-463) and using subsurface temperature and pressure conditions from various sources, indicate that the amount of water likely to be dissolved in reservoir gas and subsequently produced at the surface ranges from 0.10 to $1.03 \mathrm{bbl} / \mathrm{mmcf}$ among the four fields considered here (table 1). These estimates are included as diagonal lines on water-gas plots on plates 1-5 to indicate how much of the water produced at surface could originate as water originally dissolved in reservoir gas.

Because oil and gas types are defined as a function of gas-to-oil ratios (McCain, 1990), the fluid types can be displayed on the log-log oil production versus gas production diagrams (fig. 5). Black oil types have gas-oil ratios less than 2,000 standard cubic feet per barrel (scf/bbl) and volatile oil types have gas-oil ratios of less than 3,300 scf/bbl of oil, and together they occupy the upper left corner of an oil-gas production diagram (fig. 5). In a retrograde gas reservoir, liquid condenses in the reservoir as reservoir pressure declines. Gas-oil ratios in retrograde gas reservoirs typically range from 3,300 to $50,000 \mathrm{scf} / \mathrm{bbl}$, although they can have values as high as $150,000 \mathrm{scf} / \mathrm{bbl}$; these reservoirs occupy a central diagonal band on an oil-gas diagram (fig. 5). Wet gases, also called condensate gases, have gas-oil ratios in excess of 50,000 $\mathrm{scf} / \mathrm{bbl}$ ( $<20 \mathrm{bbl}$ condensate/mmcf gas), and they occupy the lower right corner of the diagram. Dry gas produces no oil, and corresponding points are plotted in a separate rectangular box at the bottom of the diagram.

The use of bi-logarithmic plots introduced in figures 3-5 deserve further explanation. Plotting production summaries 


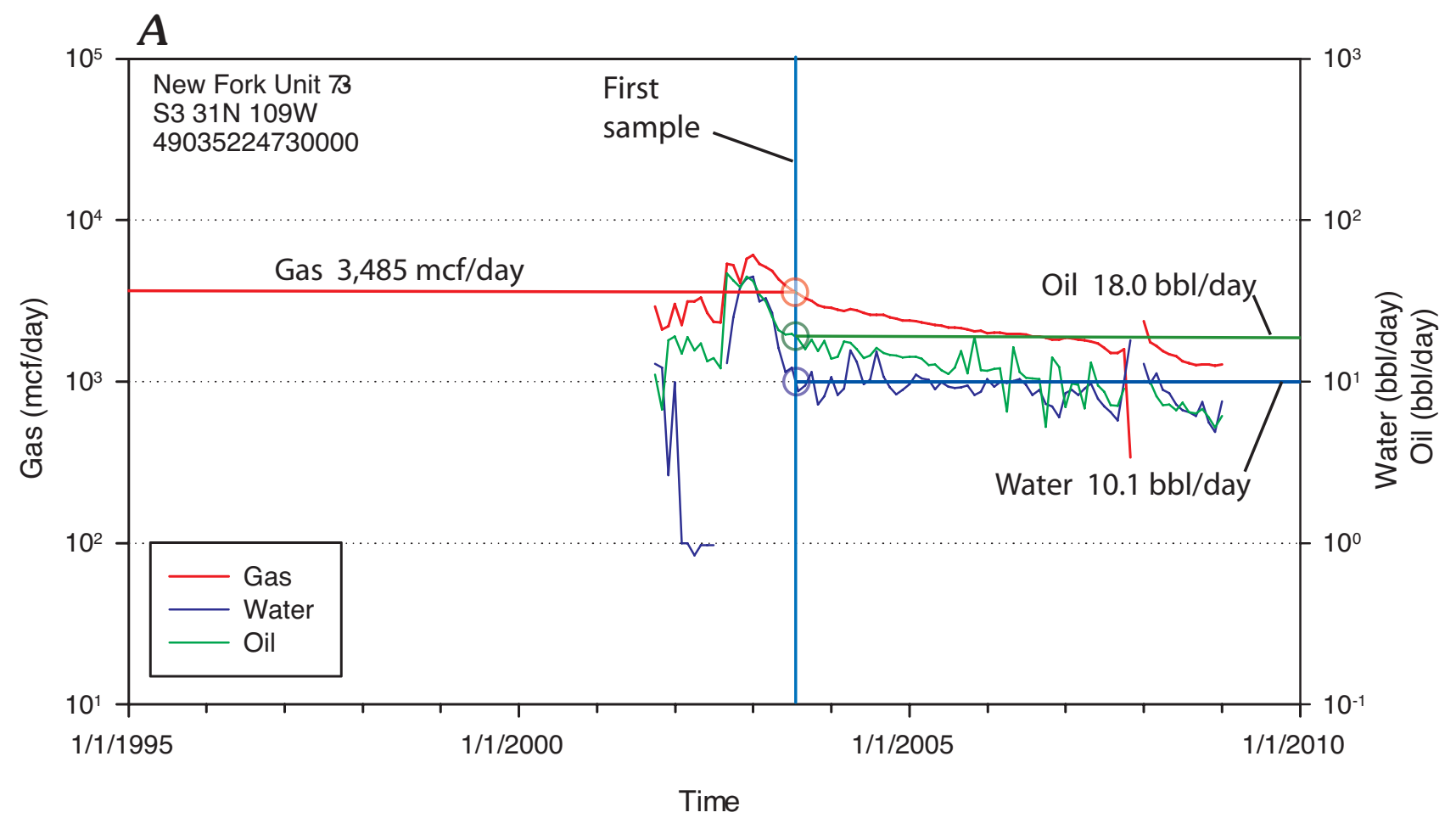

\section{B}

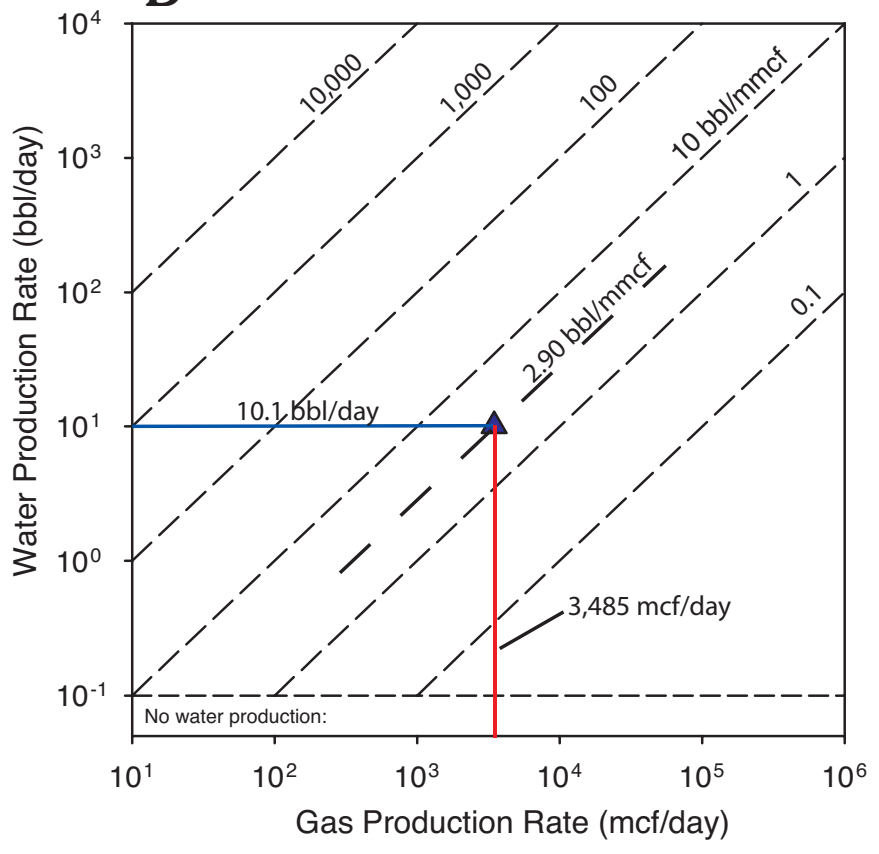

C

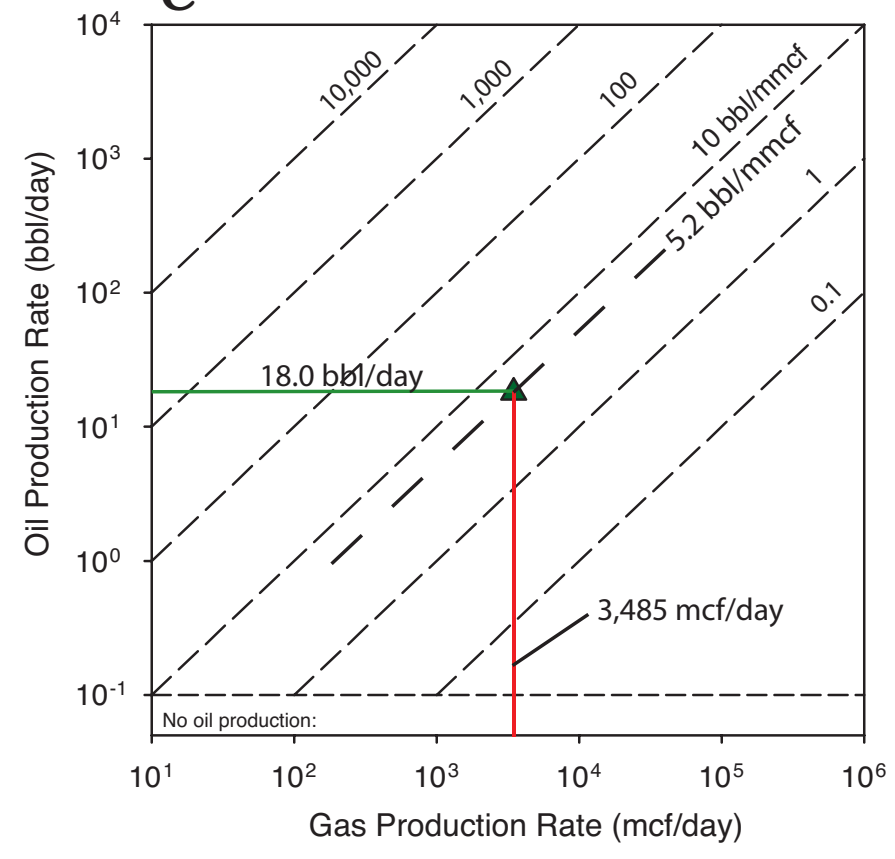

Figure 3. Example plot of fluid production versus time with corresponding bi-logarithmic production plots for the New Fork Unit 7-3 well in Pinedale field. $A$, Production of gas, water, and oil versus time. Vertical blue line indicates the first sample, which is generally about two years after onset of production. Posted values are averages for months of June, July, and August, 2003. B, Water versus gas production on logarithmic axes. Triangle symbol shows water and gas rate values from part $A$. The water:gas ratio of 2.90 barrels per million standard cubic feet (bbl/mmcf) falls on a 45-degree line. $C$, Oil versus gas production on logarithmic axes. Triangle shows oil and gas rates from part $A$. The gas:oil (or oil:gas) ratio falls on a 45-degree line. An oil:gas ratio of $5.2 \mathrm{bbl} / \mathrm{mmcf}$ is equivalent to a gas:oil ratio of 192,307 scf/bbl [mcf/day, thousand standard cubic feet per day; scf/bbl, standard cubic feet per barrel; bbl/mmcf, barrels per million standard cubic feet]. 

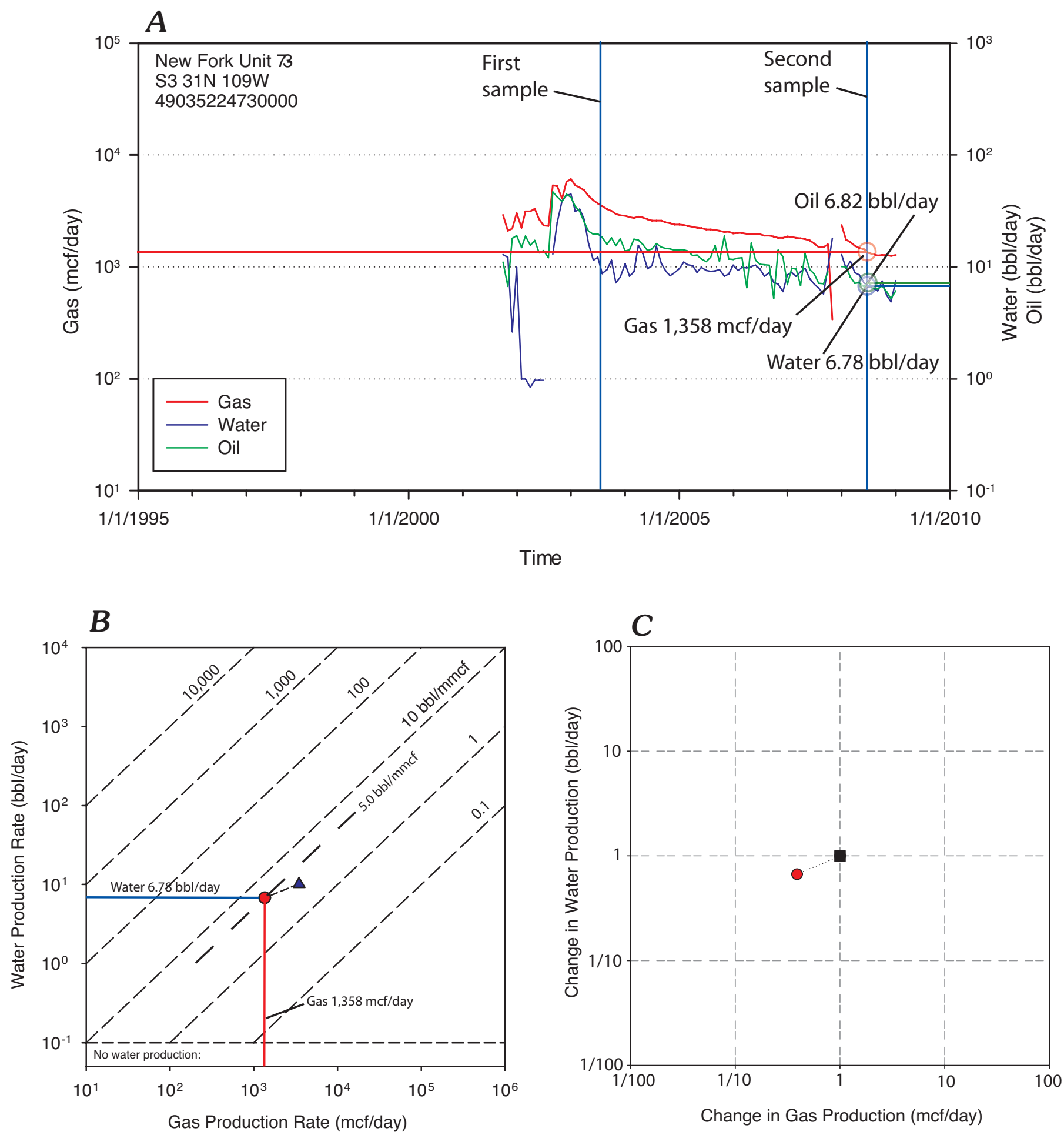

Figure 4. Example plot of fluid production versus time with vector plots of changes in production with time, for the New Fork Unit 7-3 well in Pinedale field. $A$, Production of gas, water, and oil versus time. $B$, Vector plot, with water versus gas production on logarithmic axes. The triangle designates the gas and water production at the first sample and the red circle shows production at the second sample taken five years later, thus marking the head and tail of a vector. $C$, Normalized vector plot, with change in water production versus change in gas production on logarithmic axes. Values from the first sample are placed at center of plot, so all vectors for a field share a common origin [mcf/day, thousand standard cubic feet per day; scf/bbl, standard cubic feet per barrel; bbl/mmcf, barrel per million standard cubic feet]. 
Table 1. Estimates of water released at the surface that was originally dissolved in gas in the reservoir, for pressure and temperature conditions corresponding to selected depths in four gas reservoirs. Solubility of water in gas and estimate of water retained of $33 \mathrm{lb} / \mathrm{mmcf}$ are taken from McCain (1990) [psi, pounds per square inch; lb, pounds; mmcf, millions of cubic ft; cuft, cubic ft; bbl, barrels].

\begin{tabular}{|c|c|c|c|c|c|c|c|c|c|c|}
\hline \multirow[t]{2}{*}{ Field name } & \multirow[t]{2}{*}{ Depth in reservoir } & \multirow{2}{*}{$\begin{array}{c}\text { Depth } \\
\mathrm{ft}\end{array}$} & \multirow{2}{*}{$\begin{array}{c}\text { Temperature } \\
{ }^{\circ} \mathrm{F} \\
\end{array}$} & \multirow{2}{*}{$\begin{array}{c}\text { Pressure } \\
\text { psi }\end{array}$} & \multirow{2}{*}{$\begin{array}{c}\text { Solubility of } \\
\text { water in gas } \\
\mathrm{lb} / \mathrm{mmcf}\end{array}$} & \multirow{2}{*}{$\begin{array}{c}\text { Corrected } \\
\text { for salinity } \\
\mathrm{lb} / \mathrm{mmcf} \\
\end{array}$} & \multirow{2}{*}{$\begin{array}{l}\text { Water } \\
\text { retained } \\
\mathrm{lb} / \mathrm{mmcf}\end{array}$} & \multicolumn{3}{|c|}{ Water released at separator } \\
\hline & & & & & & & & $\mathrm{lb} / \mathrm{mmcf}$ & cuft/mmcf & $\mathrm{bbl} / \mathrm{mmcf}$ \\
\hline Jonah & Average depth & 9,900 & 192 & 5,800 & 170 & 167 & 33 & 134 & 2.14 & 0.38 \\
\hline Pinedale & Top depth & 7,700 & 135 & 3,696 & 70 & 69 & 33 & 36 & 0.57 & 0.10 \\
\hline Pinedale & Average depth & 10,400 & 169 & 6,344 & 105 & 103 & 33 & 70 & 1.12 & 0.20 \\
\hline Pinedale & Bottom depth & 13,100 & 202 & 11,790 & 160 & 157 & 33 & 124 & 1.98 & 0.35 \\
\hline Wamsutter & Top depth & 8,000 & 168 & 4,800 & 130 & 127 & 33 & 94 & 1.51 & 0.27 \\
\hline Wamsutter & Mid-depth & 10,500 & 208 & 6,300 & 230 & 225 & 33 & 192 & 3.08 & 0.55 \\
\hline Wamsutter & Bottom depth & 13,000 & 248 & 7,800 & 400 & 392 & 33 & 359 & 5.76 & 1.03 \\
\hline Stagecoach Draw & Average depth & 8,088 & 140 & 3,397 & 75 & 74 & 33 & 41 & 0.65 & 0.12 \\
\hline
\end{tabular}




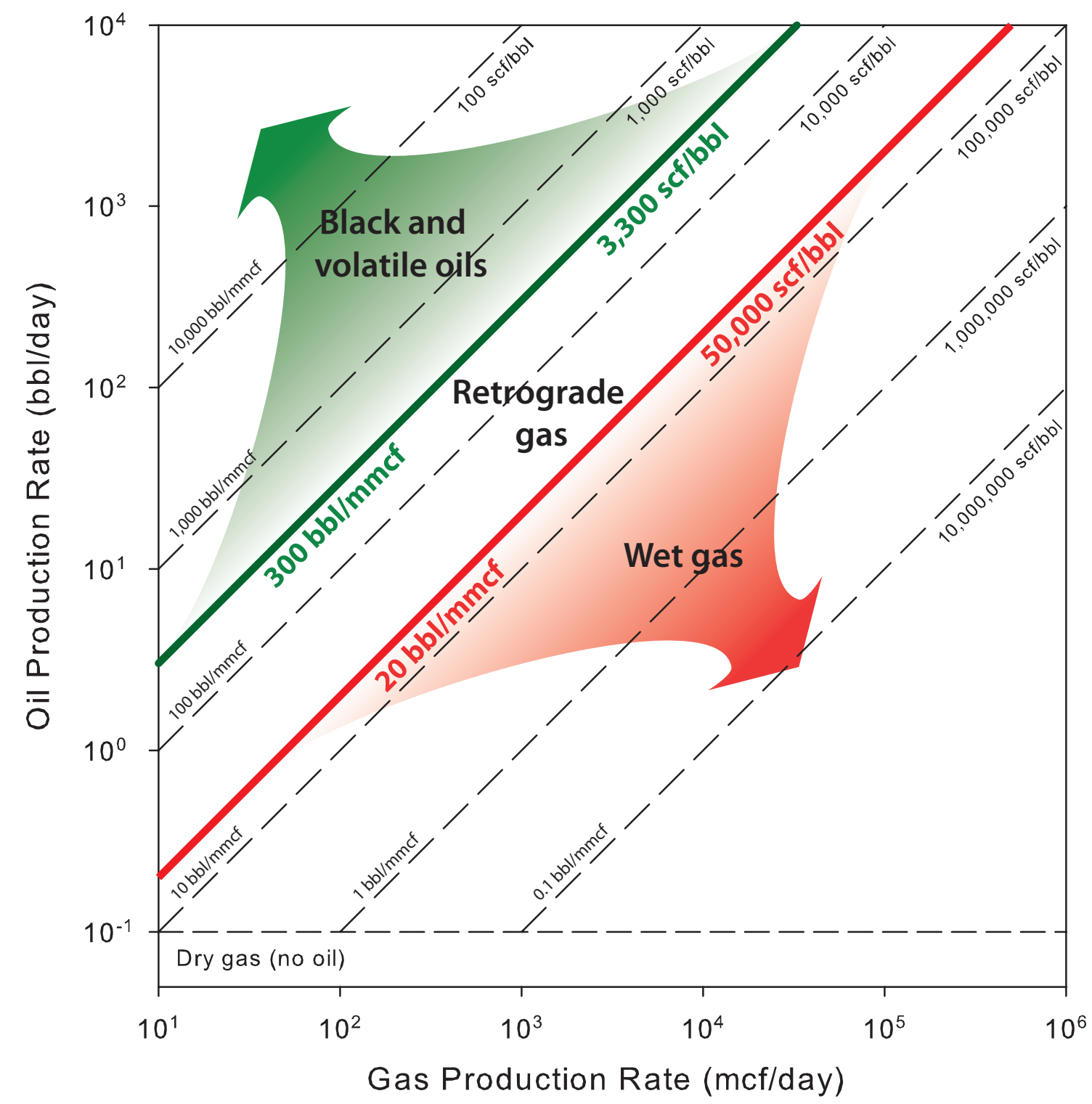

Figure 5. Oil and gas types plotted on a log-log diagram of oil and gas production rates. Fields indicate three reservoir fluid types, based on McCain (1990) [scf/bbl, standard cubic feet per barrel; bbl/mmcf, barrels per million standard cubic feet; bbl/day, barrels per day; mcf/day, thousand standard cubic feet per day.].

on logarithmic scales allows display of a wide range of values (fig. 6A) - the difference between 0.1 and 0.2 is as visible as the difference between 10,000 and 20,000. In other words, the spacing between constant multiples is maintained for all values. However, when a portion of the production data plotted on logarithmic scales are replotted on linear scales, most of the data are compressed into a small area in the lower left corner of the plot (fig. $6 B$ ). If all the data in figure $6 A$ had been replotted into figure $6 B$, the compression would be more severe. Lines of constant water-gas ratio, which form a fan-shaped array on a plot with linear scales (fig. 6B), instead plot as parallel lines on logarithmic scales (fig. 6A).
Consequently, it is easier to count the populations within specified ranges of constant water-gas ratios on logarithmic plots than on linear plots. Thus, there are two reasons to use logarithmic scales in summarizing production data: (1) large ranges of data can be represented and compared, and (2) populations lying within a specified range of water-gas ratios can be counted and compared.

Maps, production plots for selected wells, and summary plots of data are presented in plates 1, 2, and 5 for Jonah, Pinedale and Stagecoach Draw fields. Because of the size and complexity of the Greater Wamsutter area, plates 3 and 4 contain maps and summary plots of data; production plots are 

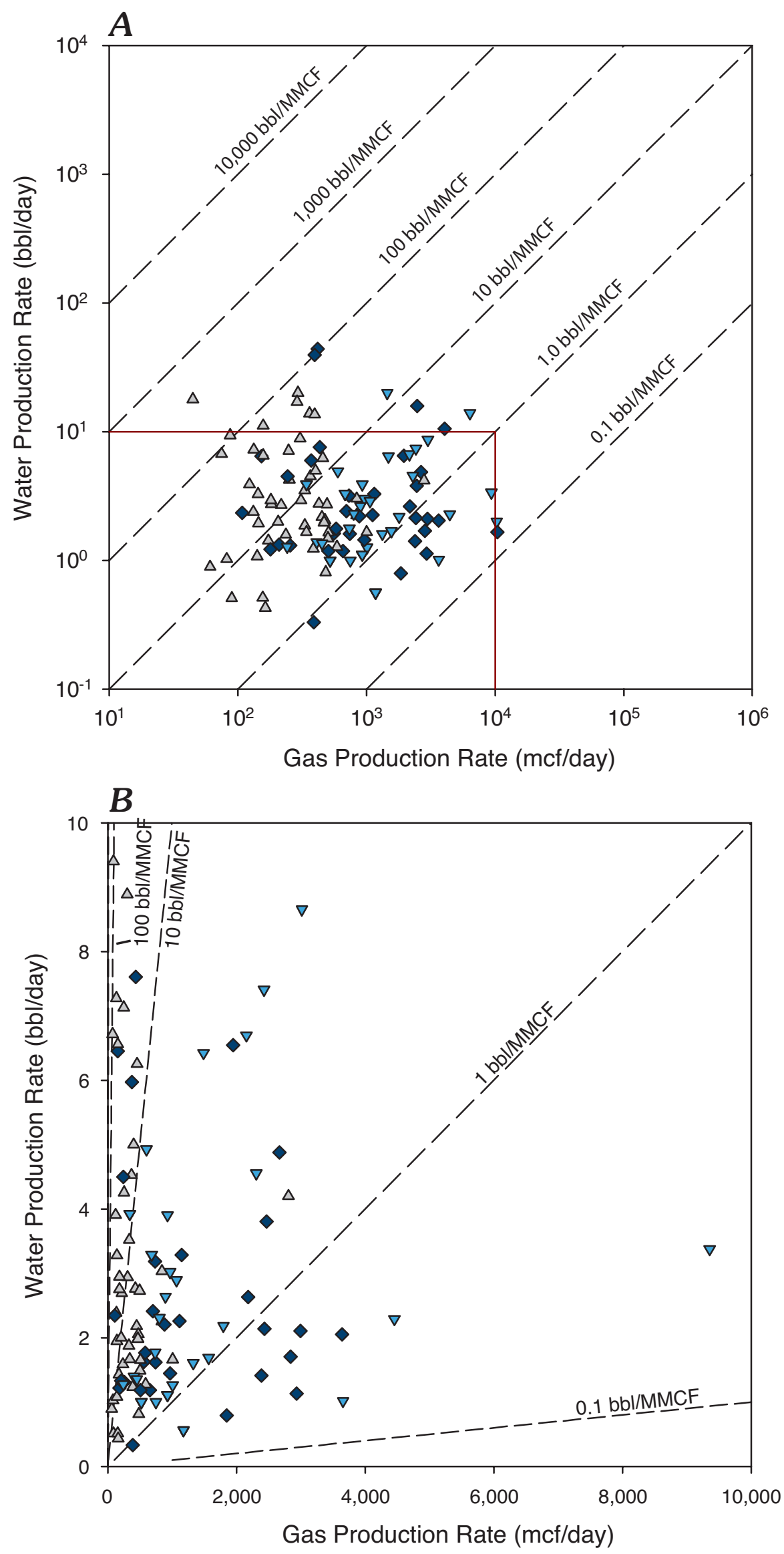

Figure 6. Demonstration of the difference between a plot with logarithmic scales $(A)$ and a plot with linear scales $(B)$, using water and gas production data as an example. Data within the red lines in $(A)$ are replotted in $B$. Lines of constant water-gas ratio that are parallel in $A$ are fan-shaped in $B$. 
not included. The four appendices contain numerical values of fluid production from the first and second samples and the location of each well. Production records and other data for this study were drawn from the IHS-production database (IHS Energy, 2009). Well locations were taken from the web site of the Wyoming Oil and Gas Conservation Commission (2009).

\section{Jonah Field}

General setting. Gas reservoirs in Jonah field are in fluvial sandstones of the Lance Formation (fig. 2), with some contribution locally from the upper part of the Mesaverde Formation (Dubois and others, 2004). The field is bounded by two shear fault zones that form a wedge-shaped structural block; variations in gas production rates are related to faults segmenting the field (fig. 1-1 of pl. 1). Depths of perforated intervals in the 18 wells examined in this study range from 7,852 to $11,986 \mathrm{ft}$. Various authors (for example, Dubois and others, 2004; Coskey, 2004) have proposed that the Jonah reservoirs were charged by gas migrating upwards from source rocks deeper than the Lance Formation.

Porosity and permeability. Porosity is generally less than 10 percent and permeability less than $0.1 \mathrm{md}$, although both limits are exceeded, particularly in the upper Lance Formation (Dubois and others, 2004; Shanley, 2004). Various lines of evidence indicate that fractures do not play a role in fluid production in Jonah (Dubois and others, 2004).

Pressure and temperature. The reservoir at Jonah field is overpressured, with pressure increasing from hydrostatic at the base of the Fort Union Formation at approximately 7,500 $\mathrm{ft}$ depth to an overpressured condition with a pressure-depth ratio of $0.7 \mathrm{psi} / \mathrm{ft}$ at $13,000 \mathrm{ft}$ (Dubois and others, 2004). A compilation of temperature data from long-term pressure buildup tests from the Pinedale-Jonah area indicates a temperature of $187^{\circ}$ to $198^{\circ} \mathrm{F}$ at $10,000 \mathrm{ft}$ (fig. 6 of Coskey, 2004).

Thermal maturity. Based on data from three wells within Jonah field, the vitrinite reflectance at 10,000-ft depth is 0.78 percent (table 1 of Coskey, 2004).

Well selection. Well selection is based on continuity of record and spatial coverage of the reservoir (fig. 1-1 of pl. 1). Well locations are shown relative to areas or high, medium, and low estimated ultimate recovery (EUR), based on mapping by Dubois and others (2004).

Gas production. Average gas production at the first sample for 18 wells was 2,182 mcf/day; declining to an average of 1,100 mcf/day at the second sample five years later. Values for individual wells are tabulated in appendix 1 and displayed in figures 1-2 through 1-4 of plate 1. Gas production at the first sample is highest (average of 2,950 mcf/day) in the five wells located in the areas with EURs greater than $10 \mathrm{bcf}$, as mapped by Dubois and others (2004), and least (average of $1,204 \mathrm{mcf} /$ day) in the four wells with EURs less than 5 billion cubic feet (bcf).

Oil-gas ratio. Oil-gas ratios are constant over ten years of production, as gas and oil decline at similar rates (figs. 1-6 through 1-23 of pl. 1). Oil-gas ratios from 18 first samples range from 7 to $17.5 \mathrm{bbl} / \mathrm{mmcf}$, with an average of $9.9 \mathrm{bbl} /$ mmcf (fig. 1-3 of pl. 1). The trend on the oil-gas plot is parallel to the diagonal, and falls below the upper limit of $20 \mathrm{bbl} /$ mmcf that defines the wet gas field (fig. 5), indicating that the oil is condensate. The oil-gas ratios reported here are for the total production intervals in individual wells, so any dependence on depth is obscured. However, based on observations from isolated production intervals, Dubois and others (2004) reported that the oil-gas ratio increases with depth from about $12 \mathrm{bbl} / \mathrm{mmcf}$ near the top of the Lance Formation to $45 \mathrm{bbl} /$ mmcf at 2,500 $\mathrm{ft}$ below the top of the Lance.

Water production. The erratic character of the water production with time is attributed to the low volumes of produced water, making measurement of water volume difficult; in some wells, the second water sample was obtained by extrapolation or interpolation. Water-gas ratios from first samples range from 0.67 to $3.9 \mathrm{bbl} / \mathrm{mmcf}$ (appendix 1), with an average of $2.0 \mathrm{bbl} / \mathrm{mmcf}$, which is more than the $0.38 \mathrm{bbl} / \mathrm{mmcf}$ that could be dissolved in gas at reservoir conditions at $9,900 \mathrm{ft}$ (table 1 and 45-degree blue line of fig. 1-2 of pl. 1), indicating that some free water is being produced. Water-gas ratios are lowest, $1.4 \mathrm{bbl} / \mathrm{mcf}$, in the five wells located in areas mapped as having EURs greater than $10 \mathrm{bcf}$ (pl. 1), and highest, 3.2 $\mathrm{bbl} / \mathrm{mcf}$, in the four wells located in areas mapped as having EURs less than 5 bcf.

\section{Pinedale Field}

General setting. The Pinedale Anticline, depicted as an asymmetric structure bounded on the west by a high-angle reverse fault, and with a length of 35 miles and a width of 6 miles, is the largest structure in the northern Green River Basin (Law and Johnson, 1989). Gas production documented in this report is from the Lance Formation. In the Wagon Wheel 1 well (location in fig. 2-1 of pl. 2), the top of the Lance Formation was reached at 7,520 ft and the underlying Ericson Sandstone was reached at 13,065 ft (Law and Johnson, 1989). The gas accumulation in Pinedale Anticline was characterized as a basin-centered type and estimated to contain 159 trillion cubic feet of gas (Charpentier and others, 1989). Gas production commenced in the 1990s, as shown by production graphs in this report, with gas production increasing annually from a level exceeding 6 billion cubic feet in 1999 (Wyoming Oil and Gas Conservation Commission, 2009).

Stratigraphy. A stratigraphic chart for the Pinedale anticline shows the base of the Lance Formation coincident with the top of the Ericson Sandstone (Law and Johnson, 1989). However, field operators state that upper Mesaverde strata are present above the top of the Ericson Sandstone (Chapin and others, 2009) and refer to the reservoir as the undifferentiated Lance/Mesaverde pool, with its base at the top of the Ericson Sandstone (Quint and others, 2006). Chapin and others (2009) 
indicate that some production also comes from the unnamed Tertiary unit that overlies the Lance Formation.

Porosity and permeability. Sandstones of the Lance Formation are predominantly fine grained. Based on 858 core samples, porosity is generally less than 12 percent, with average porosity values of 7.7 and 7.6 for the Lance and Mesaverde, respectively (Chapin and others, 2009). Permeability values are generally less than $44 \mu \mathrm{d}$ with average values of 15.8 and $6.4 \mu \mathrm{d}$ for the Lance and Mesaverde, respectively, measured at in-situ stress conditions (Chapin and others, 2009).

Thermal maturity. In the Wagon Wheel 1 well, measured vitrinite reflectance values reach 0.7 percent at $7,100 \mathrm{ft}, 0.8$ percent at $8,500 \mathrm{ft}$, and 1.0 percent at $11,000 \mathrm{ft}$ (Law, 1984). The sequence of gas generation, structural deformation, and uplift and erosion is discussed by Law (1984). A burial history and kinetic model for the Wagon Wheel 1 well shows computed values of vitrinite reflectance exceeding 0.8 percent in the lower one-third of the Lance Formation; a value of 0.8 percent represents peak gas generation in Type-III source rocks (Roberts and others, 2005). Another burial history and kinetic model for the Wagon Wheel 1 well shows higher levels of themal maturity, with vitrinite reflectance exceeding 1.0 percent in the lower two-thirds of the Lance Formation (Brown, 2005). Examining the ratio of total organic carbon and void ratio (pore space / solid volume), Brown (2005) concludes that the Lance Formation lacks sufficient organic matter to have self-sourced the gas, and that gas must have migrated from deeper sources into the Lance.

Pressure and temperature. The reservoir is overpressured, with pressure increasing from near-hydrostatic at 7,000 feet depth to a pressure-depth ratio of $0.9 \mathrm{psi} / \mathrm{ft}$ at $13,500 \mathrm{ft}$. Stepwise increases in pressure with depth show the vertical isolation of stacked reservoirs (Quint and others, 2006). A compilation of temperature data from long-term pressure buildup tests from the Pinedale-Jonah area indicates a temperature of $187^{\circ}$ to $198^{\circ} \mathrm{F}$ at $10,000 \mathrm{ft}$ (fig. 6 of Coskey, 2004).

Well selection. Well selection is based on continuity of record and spatial coverage of the reservoir (fig. 2-1 of pl. 2). The wells that are not highlighted on the map (fig. 2-1 of pl.

2) represent a significant fraction of the existing wells, chosen to indicate the spatial extent of the field. Most wells selected have continuous records, such as Stewart Point 3-28 and 6-32V (figs. 2-6 and 2-7 of pl. 2), but other production records have significant gaps, such as Pinedale Federal 13-19 and Petrogulf State 36-1 (figs. 2-13 and 2-14 of pl. 2). Despite the lack of continuity, these latter wells were retained so that wells with high water-gas ratios could be included in the sample set. Thirty wells are included in this study; all thirty have production data for gas, water, and oil at both the first and second sample times (appendix 2, pl. 2)

Gas production. Gas production rates at the first-sample times range from 294 to 5,759 mcf/day in our 30-well sample (appendix 2). Average gas production at the first sample for 30 wells was 1,632 mcf/day; declining to an average of 749 $\mathrm{mcf} / \mathrm{day}$ at the second sample five years later. The Vible 1 well (fig. 2-11 of pl. 2), which has the lowest gas (294 mcf/ day) and water $(1.9 \mathrm{bbl} /$ day) first-sample production rates, was put on production in 1995, earlier than any other well in our 30-well sample, so its low flow rates may be attributed to operational limitations, as it is located near the crest of the anticline where gas production tends to be higher than elsewhere. The Antelope 15-4 well (fig. 2-17 of pl. 2), with the highest first-sample gas production $(5,759 \mathrm{mcf} /$ day $)$ of all wells, is located at the southern tip of Pinedale field. Gas production tends to be lower and more erratic in wells north and south of the crest of the anticline, as shown by the first-sample production rates posted on the map (fig. 2-1 of pl. 2).

Oil-gas ratio. Oil (condensate) production tracks gas production closely, as can be seen by inspection of the production-time plots (figs. 2-6 to 2-17 of pl. 2), and also by the cluster of data points on the oil-gas plot (fig. 2-3 of pl. 2) that forms a diagonal trend with an average value of 7.65 barrels of oil per mmcf gas, which lies in the wet gas field (fig. $6)$.

Water production. First-sample water production rates range from 1.9 to $148 \mathrm{bbl} /$ day (fig. 2-2 of pl. 2, appendix 2). Two wells with high water production, Antelope 11-4 and Antelope 15-4 with first-sample rates of 69 and $91 \mathrm{bbl} / \mathrm{day}$, respectively, are located in the southern extremity of the field. First-sample water-gas ratios (fig. 2-2 of pl. 2) range from 2.9 to 122 barrels of water per mmcf of gas, although most values fall in the range 7 to 28 barrels of water per mmcf of gas. These values are roughly 50 times as much water as can be dissolved in gas at reservoir conditions, showing that free water is being produced. Nine wells with water-gas ratios of less than $10 \mathrm{bbl} / \mathrm{mmcf}$ are highlighted in yellow on the watergas plot (fig. 2-2 of pl. 2) and on the map (fig. 2-1 of pl. 2), which shows that the wells with the lowest water-gas ratios are located near the crest of the anticline.

Water and gas decline rates. Water and gas production rates tend to track with time, that is, both water and gas decline at about the same rate, as can be seen by (1) inspection of production versus time plots (figs. 2-6 through 2-17 of pl. 2), by (2) the vectors in the magnitude plots (fig. 2-4 of pl. 2), which are nearly parallel with the diagonal lines that indicate constant ratios of water and gas, and by (3) the vectors in the normalized vector plots (fig. 2-5 of pl. 2), which cluster around the 1:1 diagonal. One exception is well Petrogulf State 36-1 (fig. 2-14 of pl. 2), which has a high water production rate that declines more rapidly than the gas rate.

\section{Greater Wamsutter Field}

General setting. Wells and fields considered part of the Greater Wamsutter producing area are shown in figure 7. The Greater Wamsutter field consists of areas that were originally separate fields but have partially coalesced over time as drilling progressed (fig. 7). The north-south granularity of the well patterns is due to the elongate geometry of sandstone complexes that comprise the more productive units generally 


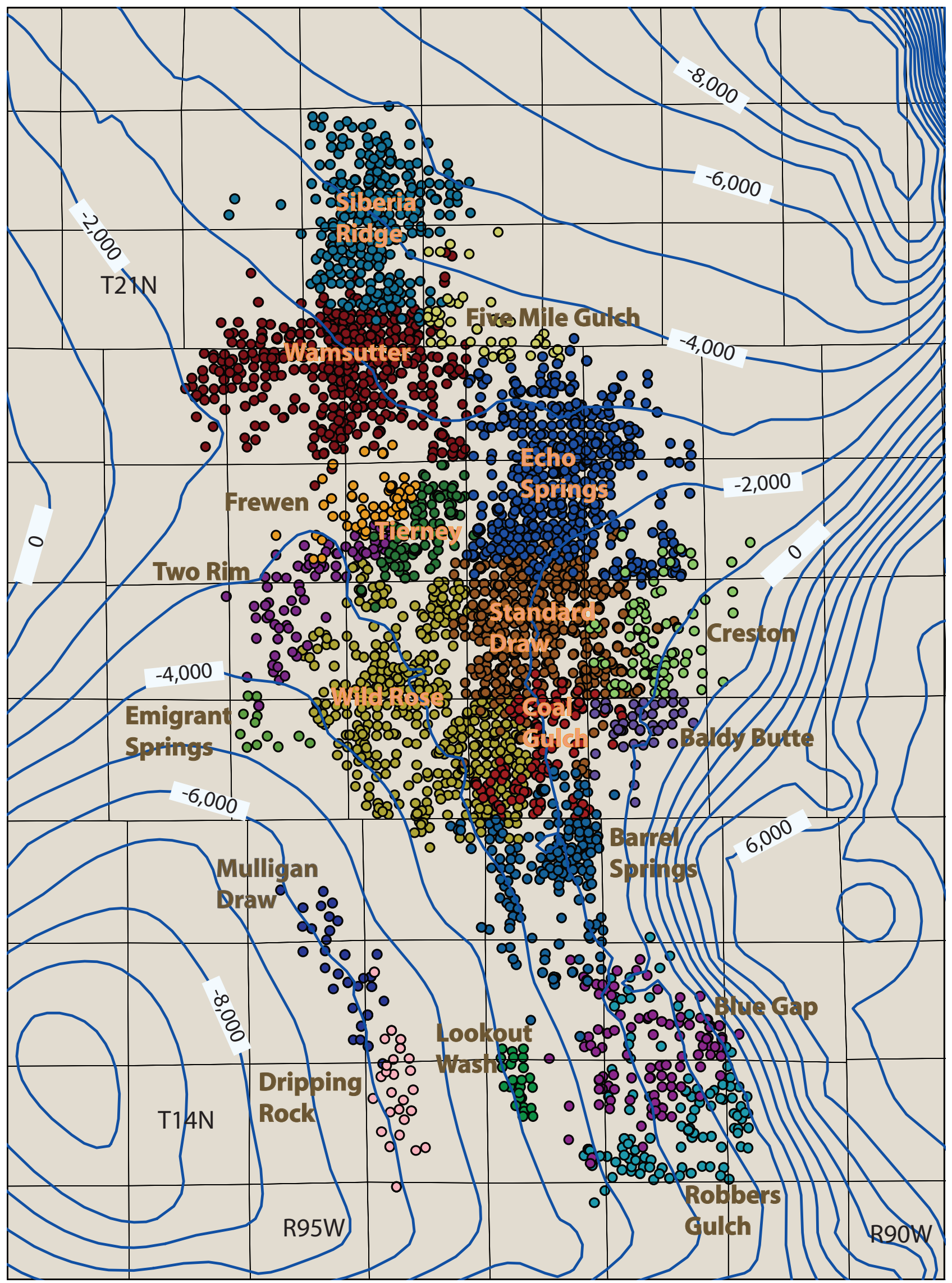


Figure 7 (facing page). Location of gas fields and wells producing gas and oil from the Almond Formation, eastern part of Greater Green River Basin. All fields are considered part of the Greater Wamsutter producing area; colored dots indicate the wells within each field. Contours show top of Mesaverde Formation, from Johnson and others (2005).

referred to as upper Almond. Gas is produced from both the upper Almond and deeper non-marine units, referred to as the main Almond. In wells where both the upper and main parts of the Almond Formation were perforated, the production is classed as combined Almond.

Pressure. McPeek (1981) delineated an overpressured area in the Mesaverde Formation in the eastern part of the Greater Green River Basin, showing 10 wells between T. 15 N. and T. 22 N. and R. 92 W. and R. 95 W. with pressure-depth ratios between 0.54 and $0.64 \mathrm{psi} / \mathrm{ft}$. Ratios of initial pressures to depth for fields included in this study are Creston, 0.56 psi/ft; Echo Springs, 0.53 psi/ft; Robbers Gulch, 0.45 psi/ft; Siberia Ridge, 0.62 psi/ft; Tierney, 0.69 psi/ft; and Wamsutter, $0.63 \mathrm{psi} / \mathrm{ft}$ (Martinsen and Christensen, 1992). A compilation of pressure versus elevation for the Almond Formation in an area ranging from T. $18 \mathrm{~N}$. to T. $23 \mathrm{~N}$. and R. $88 \mathrm{~W}$. to R. 112 $\mathrm{W}$. indicates overpressuring below an elevation of $-1,000 \mathrm{ft}$ (Forster and Horne, 2005, fig.7); below this elevation, which corresponds to a depth of approximately $7,800 \mathrm{ft}$, drillstem tests recovered little water and water production is also low (Forster and Horne, 2005, fig.8).

Porosity and permeability. Porosity and permeability in the Almond Formation decrease with increasing presentday depth of burial (Keighin and others, 1989). Porosity and permeability are generally greater in the upper than in the main parts of the Almond Formation. Samples from the upper Almond mostly range from 10 to 20 percent porosity with most permeability values ranging from 0.1 to $20 \mathrm{md}$, whereas samples from the main body of the Almond range from 1 to 15 percent porosity with permeability generally less than $1 \mathrm{md}$ (Martinsen, 1998).

Well selection. Records with adequate continuity and completeness of gas, oil, and water data were included in the data set for this study. Wells with water records that were nearly identical with water records in neighboring wells were excluded; it was assumed that the water production was prorated among wells. Geographical coverage was also a consideration in well selection. Wells with comingled production from the Lewis Shale were excluded. The selected data set is comprised of 117 wells (appendix 3, fig. 3-1 of pl. 3). Determination of whether production intervals were located in the upper, main, or combined Almond was based upon well records (IHS Energy, 2009) and inspection of well logs (Wyoming Oil and Gas Conservation Commission, 2009). Prior to production, wells were stimulated by acidizing, hydraulic fracturing, or a combination of acidizing and hydraulic fracturing.

Production plots. Three examples of production versus time illustrate the nature of fluid production from the Almond
Formation and also show some of the problems encountered in selecting time intervals to represent that production (fig. 8). The Amoco Unit $\mathrm{C} 1$ well in the Echo Springs field produces from a 33-ft perforated interval in the upper part of the Almond. Production commenced in late 1979 and continued through 2007. Water records commenced in 1984, so the first sample is taken in 1984 rather than two years after commencement of production, a choice that in this case does not alter the flow rate magnitudes. A slow but steady decrease in gas production, in this case about one-third over 20 years, is characteristic of gas recovery from the Almond Formation, as also shown by the vector plots (fig. 3-23 of pl. 3). Erratic low flow of oil and water are observed in most wells- the two time intervals shown in figure 8 are positioned to capture the general trend of all three fluid production rates.

The Barrel Springs Unit II 40-6 well produces from both the upper and main parts of the Almond Formation (fig. 8). Well logs show that the thickness of the upper part of the Almond is $20 \mathrm{ft}$ and that four or five thin sandstones are present in the main part of the Almond; no perforation information is available except for the total interval of 9,351-9,680 ft. In this example, the recorded water production from 1992 to 2002 appears to be unreliable, so the second time interval is placed at early 1990, requiring that the first time interval be placed in late 1984 - an acceptable compromise as the early production is consistent with long-term flow from this well.

The Tierney II Unit 2 well produces from two perforated intervals in the main Almond (fig. 8). Because of erratic water production records, the first time interval is placed three years after production commenced, rather than after two years. Gas, oil, and water all show similar slow declines with time.

Gas production. Average gas production at the first sample for 117 wells was 1,098 mcf/day; declining to an average of $636 \mathrm{mcf} /$ day at the second sample five years later. The largest first-sample gas production rates are in the central and southwest areas (figs. 3-5 and 3-8, pl. 3). Most wells in these two areas produce at rates greater than $1,000 \mathrm{mcf} /$ day. Wells in the other four areas produce at rates less than 1,000 mcf/ day and much of this low-rate production is from the Main Almond; in fact, all gas production from the main Almond is less than 1,000 mcf/day, with only one exception (fig. 4-3 of pl. 4). Gas production from the upper Almond ranges from 200 to $10,000 \mathrm{mcf} / \mathrm{day}$, and is greater than the combined upper and main Almond, which ranges from 100 to 3,000 mcf/day (fig. 4-4 of pl. 4). Shallower areas might be expected to have greater permeability and porosity and hence produce at greater rates, but this is not the case, as the east central and southeast areas are the shallowest of the six areas, but produce at the lowest rates (pl. 3).

Oil-gas ratio. All wells produce some oil or condensate; no dry gas is produced (figs. 3-2 through 3-8 of pl. 3). Oil-gas ratios are generally less than $10 \mathrm{bbl} / \mathrm{mmcf}$ in the southwest and southeast areas, well within the wet gas regime (fig. 5). Oilgas ratios differ between the two fields in the southwest area: values in the Dripping Rock field are less than $1 \mathrm{bbl} / \mathrm{mmcf}$, but are around 3 to $7 \mathrm{bbl} / \mathrm{mmcf}$ in the Mulligan Draw field (fig. 

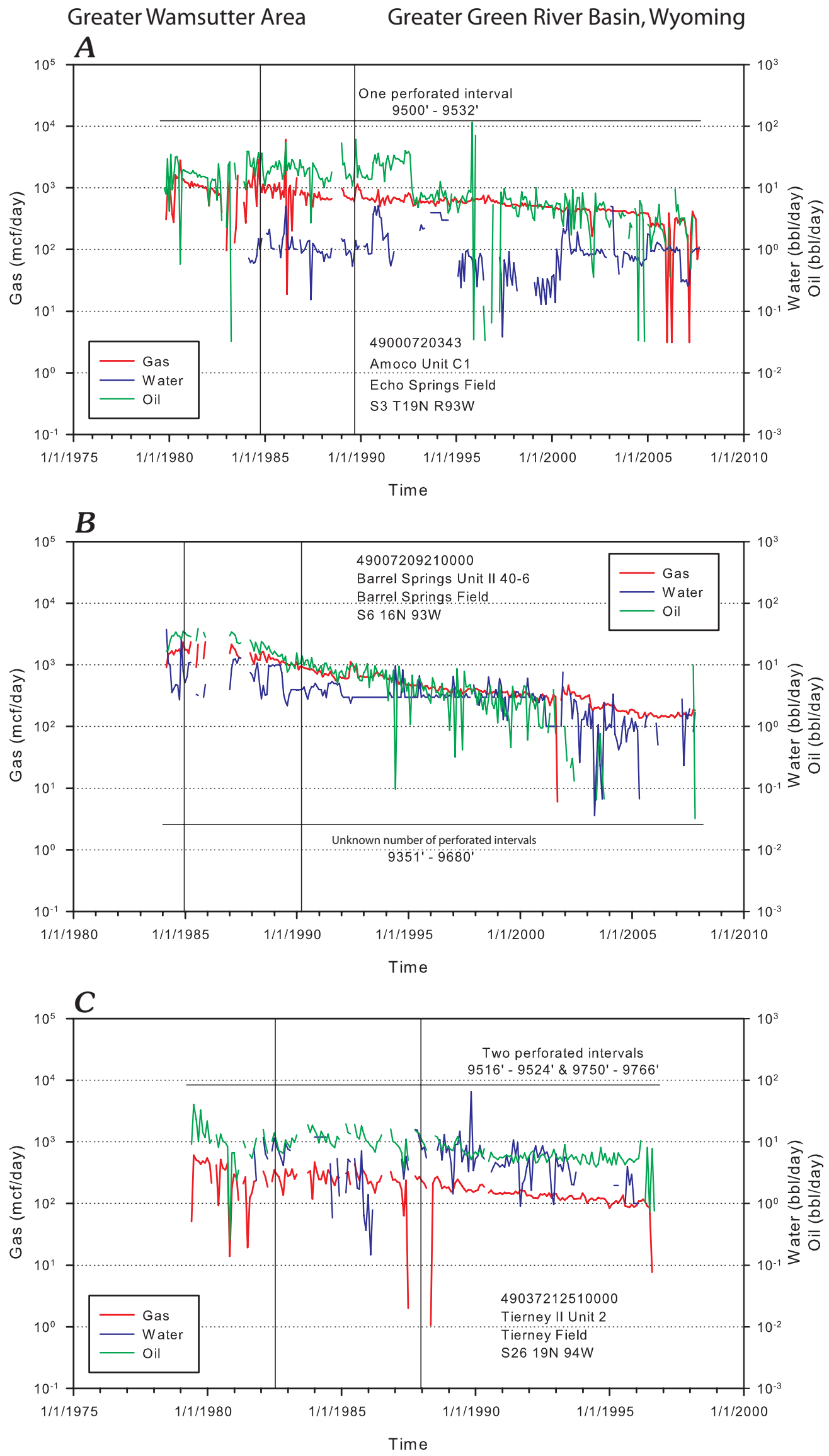
Figure 8 (facing page). Production plots from three wells in the Almond Formation. $A$, Well in Echo Springs field, producing from a 33-ft perforated interval in the upper part of the Almond. $B$, Well in Barrel Springs field, producing from a $16-\mathrm{ft}$ perforated interval in the Upper Almond and an unspecifed number of intervals in the Main Almond. C, Well in Tierney field, producing from two intervals in the main part of the Almond. Vertical lines indicate the two time intervals used to characterize production from each well.

3-8 of pl. 3), although the two fields are at comparable depths. Oil-gas ratios in many wells in the central, west central, and northwest areas are greater than $20 \mathrm{bbl} / \mathrm{mmcf}$ (figs. 3-3 through 3-5 of pl. 3), corresponding to gas-oil ratios less than $50,000 \mathrm{scf} / \mathrm{bbl}$, indicating possible retrograde conditions in the reservoir (fig. 5). Although oil-gas ratios greater than $20 \mathrm{bbl} /$ mmcf are confined to three areas, they are uniformly distributed among upper, main, and combined Almond units, so there is no apparent stratigraphic control on oil-gas ratio (figs. 4-2 through 4-4 of pl. 4). In general, oil production closely tracks gas production on plots of production versus time (fig. 8).

Water production. Water production from most wells ranges from 1 to $10 \mathrm{bbl} / \mathrm{day}$ (fig. 3-9 of pl. 3) and does not appear to vary much from area to area (figs. 3-10 through 3-15 of pl. 3). Consequently, water-gas ratios are lowest in the areas with the highest gas rates, such as the central area (fig. 3-12 of pl. 3); and are greatest in areas with the lowest gas rates, such as the southeast area (fig. 3-14 of pl. 3). Because the expected water-gas ratio varies with temperature and pressure, which vary with depth, the expected ratio was computed for depths of 8,000,10,500 and 13,000 feet (table 1); the corresponding water-gas ratios appropriate to each area in Greater Wamsutter appear as 45-degree lines in figures 3-9 through 3-15 of plate 3 and in figures 4-5 through 4-7 of plate 4 . The water-gas ratio from the upper Almond and combined upper and main Almond units is less than $3 \mathrm{bbl} / \mathrm{mmcf}$ in many wells (figs. 4-5 and 4-7 of pl. 4) and therefore a fraction (up to onehalf) of the produced water is water of condensation. On the other hand, water-gas ratios from the main Almond unit are generally greater than $3 \mathrm{bbl} / \mathrm{mmcf}$ (fig. 4-6 of pl. 4), so water of condensation can only be a small fraction of total produced water, with most of it being free, mobile water.

Water and gas decline rates. Water-gas vectors show that water rates decrease with time in most cases (figs. 3-24 through 3-29 of pl. 3), although water rates increase with time in about one-fourth of wells in the central area (figs. 3-26 of pl. 3). Increases in gas production with time are rare and small, occurring in only four wells (fig. 3-23 of pl. 3). The water-gas vectors are not well ordered, that is, increases and decreases in water production over a five-year span are independent of gas rate (figs. 3-16 through 3-22 of pl. 3). Changes in gas and water production are also independent of area, with the exception of the southwest area (figs. 3-22 and 3-29 of pl. 3 ), where the vectors are roughly co-aligned, showing that gas and water rates decline at about the same rate over a fiveyear time span. Most importantly, most wells show five-year decreases in both gas and water production of one-third or less (fig. 3-23 of pl. 3).

\section{Stagecoach Draw}

General setting. Stagecoach Draw field is located at the western terminus of the sand-rich Almond Formation (fig. 1). A facies change from shoreline to coastal and lagoon deposits forms the western limit of the field, and its position on the Sandy Bend arch provides structural control and some compartmentalization (Kovach and others, 2001).

Porosity and permeability. Based on cores from nine wells, most porosity values range from 8 to 18 percent, and most permeability values are greater than $0.1 \mathrm{md}$, with a large fraction of samples exceeding $1.0 \mathrm{md}$. Mobile water defines the downdip limits to the field (Kovach and others, 2001). Consequently, the reservoir is categorized as a conventional reservoir rather than a tight-gas reservoir.

Pressure. The field is characterized as slightly underpressured. Attempts to drill underbalanced and complete the wells without stimulation were marginally successful, but were not pursued (Kovach and others, 2001).

Well selection. Of the approximately 32 producing wells, 11 wells were selected for analysis (fig. 5-1 of pl. 1 and appendix 4).

Gas production. First-sample gas production ranged from 22 to 1,335 mcf/day, with a median value of $405 \mathrm{mcf} /$ day (appendix 4). Average gas production at the first sample for 11 wells was $494 \mathrm{mcf} /$ day; declining to an average of $127 \mathrm{mcf} /$ day at the second sample five years later. Because production is first sampled one to two years after a well is first put on production, the value can be substantially less than the production rate during the first weeks of production.

Oil-gas ratio. Oil-gas ratios follow a trend somewhat greater than the $10 \mathrm{bbl} / \mathrm{mmcf}$ diagonal (fig. 5-3 of pl. 5). With the exception of one outlier of $204 \mathrm{bbl} / \mathrm{mmcf}$, the oil-gas ratios range from 9.7 to $27 \mathrm{bbl} / \mathrm{mmcf}$, with an average of $17.3 \mathrm{bbl} /$ mmcf. These values lie at the upper end of the wet gas field (fig. 5), and are higher than the 6 to $10 \mathrm{bbl} / \mathrm{mmcf}$ range cited by Kovach and others (2001).

Water production. Water production commenced with gas production in all 11 wells (pl. 5). Average water production rate at the first-sample time was $2.7 \mathrm{bbl} /$ day, declining to $1.3 \mathrm{bbl} /$ day after five years. First-sample water production ranges from 0.7 to $7.0 \mathrm{bbl} / \mathrm{day}$ (appendix 4) and water-gas ratios range from 1.0 to $77 \mathrm{bbl} / \mathrm{mmcf}$ (fig. 5-2 of pl. 5), well above the expected amount of water of condensation (table 1, fig. 5-2 of pl. 5).

Water and gas decline rates. Over a five-year time span, water decreases at the same rate as gas in four wells, decreases at a lesser rate in five wells, and increases in two wells (fig. 5-5 of pl. 5). 


\section{Summary}

We have examined the gas, water, and oil production from selected wells in four areas in the Greater Green River Basin and conclude that:

1) The distributions of gas and water production rates in Jonah field are fairly limited, as shown by the tight clustering on the water vs gas production plot. First-sample gas production correlates with estimated ultimate recoveries as mapped by Dubois and others (2004). Water and gas decline rates are rather variable as shown by the scatter in the vectors: about one-half the wells show decreases in water production over five years and half show increases. Water-gas ratios are about 5 times greater than expected from water dissolved in gas in the reservoir.

2) In Pinedale field, both gas and water decrease in roughly the same proportion over the 5-year time span (the normalized vectors cluster around a 1:1 line). However, the magnitude of decrease varies greatly, with three wells showing very little decrease in either gas or water over five years, and three other wells showing a roughly ten-fold decrease in both gas and water. Water-gas ratio is roughly 50 times greater than can be explained by water dissolved in gas in the reservoir. Spatial control is exhibited by lower and more erratic gas production in wells north and south of the crest of the anticline than on the crest itself, and in addition, the highest water producers are located at the southern edge of the field.

3) The ranges of first-sample gas rates in Pinedale and Jonah are quite similar, and the average gas production rate for the second (five-year) sample is about one-half that of the first sample for both fields. Water rates are generally substantially higher in Pinedale than in Jonah, and water-gas ratios in Pinedale are roughly a factor of ten greater in Pinedale than in Jonah. Production data from both fields are fairly well grouped in comparison to Wamsutter and other fields in the Wind River Basin (Nelson and others, 2009), indicating that Pinedale and Jonah fields are fairly cohesive gas-water systems. Pinedale appears to be remarkably uniform in its flow behavior with time and Jonah, much smaller in area and internally faulted, exhibits a small spread in first-sample production rates.

4) In the Greater Wamsutter field, the highest gas production is from the southwest and central areas (fig. 9). In these two areas, most wells produce from the upper or the combined Almond. The southeast area, which has no production from the upper part of the Almond, has the highest water rates and the highest water-gas ratios. In the northwest area, the highest water-gas ratios are from the main part of the Almond and the lowest water-gas ratios are from the upper part of the Almond.

5) Production from the upper part of the Almond Formation is greater than from the main part of the Almond (figs. $10 \mathrm{~A}$ and 10B). Also, production from the upper Almond is more highly ordered than production from the main or combined parts of the Almond Formation, in that scatter of the first picks is somewhat less (figs. 10A, B, C) and the change vectors show water generally decreasing with gas (figs. $10 D, E, F$ ). Some wells in the main and the combined Almond show increases in water production with time whereas increases in water production are rare in the upper Almond, and a higher percentage of wells in the upper Almond show water decreasing at the same rate as gas than in the main or combined Almond (figs. 10D, E, F).

6) In Stagecoach Draw field, the gas production rate after five years is about one-fourth that of the first sample, whereas in Pinedale, Jonah, and Greater Wamsutter fields, the production rate after five years is about one-half that of the first sample. The higher decline rates in individual wells can be seen by comparing the long normalized vectors for Stagecoach Draw field (fig. 5-5 of pl. 5) with the shorter vectors of the other three fields (fig. 1-5 of pl. 1, fig. 2-5 of pl. 2, and figs. 4-11 through 4-13 of pl. 4). The gas decline rate seems to be the outstanding feature distinguishing Stagecoach Draw field, which is characterized as a conventional field, from Pinedale, Jonah, and Greater Wamsutter fields, which are generally characterized as tight-gas accumulations.

7) Oil-gas ratios are fairly consistent within Jonah, Pinedale, and Stagecoach Draw fields (fig. 1-3 of pl. 1, fig. 2-3 of pl. 2, and fig. 5-3 of pl. 5), suggesting similar chemical composition and pressure-temperature conditions within each field, and are less than the $20 \mathrm{bbl} / \mathrm{mmcf}$ upper limit for wet gas (fig. 5). However, oil-gas ratios vary considerably from one area to another in the Greater Wamsutter field (figs. 3-3 through 3-8 of pl. 3), demonstrating a lack of commonality in either chemistry or pressure-temperature conditions among the six areas.

8) In all wells in the four fields examined here, water production commences with gas production - there are no examples of wells with water-free production and no examples where water production commences after first-sample gas production. The fraction of records with water production higher in the second sample than in the first sample varies from field to field—Jonah field, 11 of 18 wells; Pinedale field, 0 of 30 wells; Greater Wamsutter field, 20 of 117 wells; and Stagecoach Draw field, 2 of 11 wells. Most wells have water-gas ratios exceeding the amount that could exist dissolved in gas at reservoir pressure and temperature.

\section{Acknowledgments}

We benefited from discussions with Mark Kirschbaum, Tom Finn, and Ron Johnson of the USGS and Ed Coalson of Coyote Oil, and from reviews by Mark Kirschbaum and Troy Cook of the USGS. 

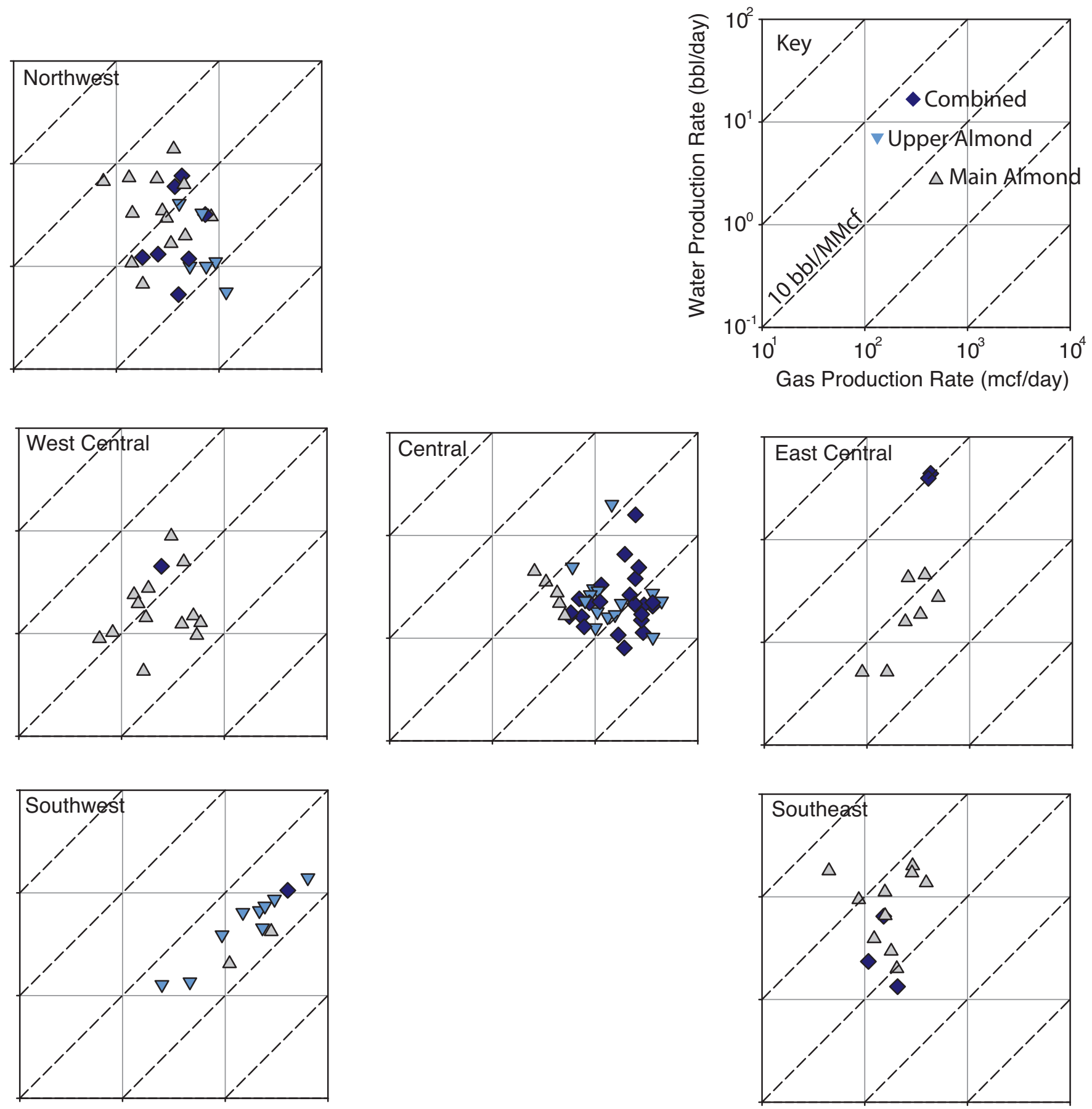

Figure 9. Plots of first-sample water against gas production rates for six areas within the Greater Wamsutter field. A water-gas ratio of $10 \mathrm{bbl} / \mathrm{mmcf}$ forms the main diagonal in all six plots, as indicated in the key in the upper right.

\section{References Cited}

Brown, A., 2005, Effects of exhumation on gas saturation in tight gas sandstones, Chapter 3 in Bishop, M.G., Cumella, S.P., Robinson, J.W., and Silverman, M.R., eds., Gas in low permeability reservoirs of the Rocky Mountain region: Rocky Mountain Association of Geologists 2005 Guidebook CD, Denver, Colorado, p. 33-50. 

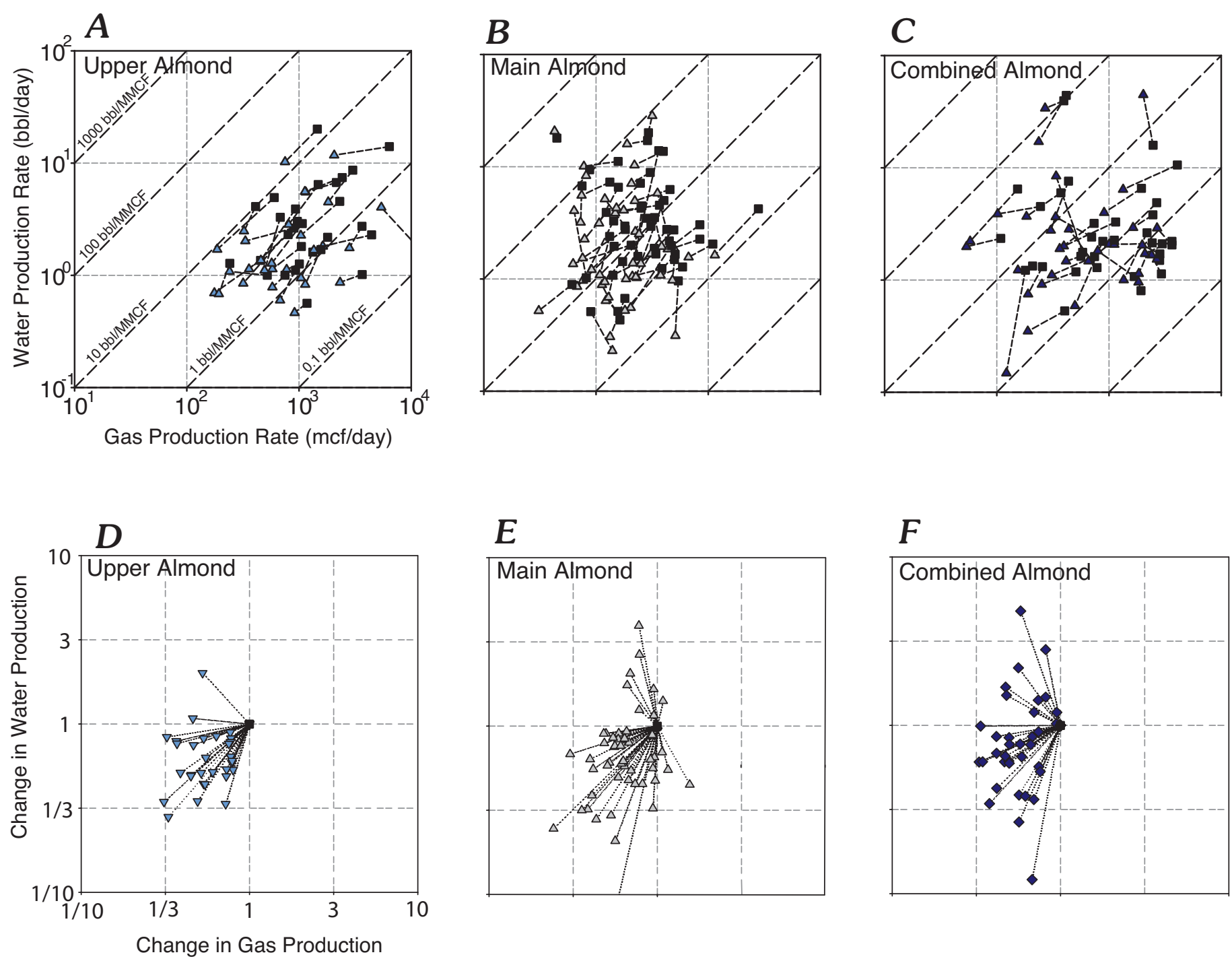

E

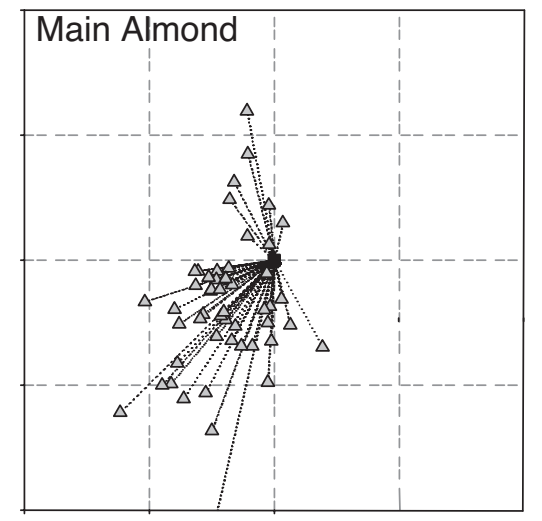

$F$

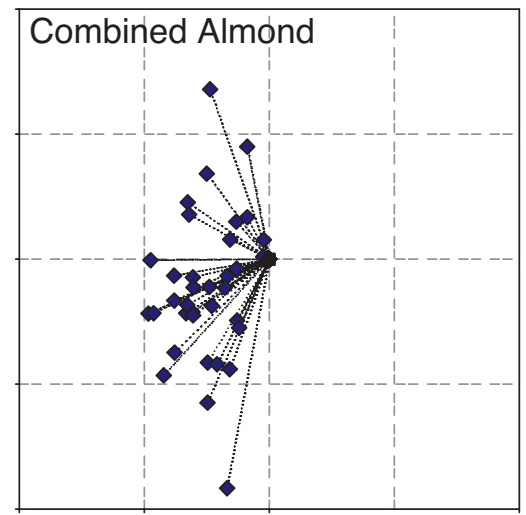

Figure 10. Water and gas production rates displayed as vector plots for the $A$, upper; $B$, main; and $C$, combined parts of the Almond Formation for all wells in the Greater Wamsutter field. The same data are plotted on normalized vector plots $D, E$, and $F$ to show relative change in gas and water production rates over a five-year time period.

Chapin, M.A., Govert, A., and Ugueto, G., 2009, Examining detailed facies and rock property variation in Upper Cretaceous, tight gas reservoirs, Pinedale Field, Wyoming, abstract and poster: American Association of Petroleum Geologists Annual Convention and Exhibition Abstracts Volume, Denver, Colorado, p. 39.

Charpentier, R.R., Law, B.E., and Prensky, S.E., 1989, Quantitative model for overpressured gas resources of the Pinedale Anticline, Wyoming, Chapter I, in Law, B.E., and Spencer, C.W., eds., Geology of tight gas reservoirs in the Pinedale Anticline area, Wyoming, and at the Multiwell Experiment Site, Colorado: U.S. Geological Survey Bulletin 1886, 13 p.
Coskey, R.J., 2004, Burial-history modeling of the Jonah Field area: an unusual and possibly unique gas accumulation in the Green River Basin, Wyoming, Chapter 7, in Robinson, J.W., and Shanley, K.W., eds., Jonah Field: Case study of a tight-gas fluvial reservoir, American Association of Petroleum Geologists Studies in Geology 52, Rocky Mountain Association of Geologists 2004 Guidebook, p. 93-125.

Dubois, D.P., Wynne, P.J., Smagala, T.M., Johnson, J.L., Engler, K.D., and McBride, B.C., 2004, Geology of Jonah Field, Sublette County, Wyoming, Chapter 5, in Robinson, J.W., and Shanley, K.W., eds., Jonah Field: Case study of a tight-gas fluvial reservoir, American Association of Petroleum Geologists Studies in Geology 52, Rocky Mountain Association of Geologists 2004 Guidebook, p. 37-59. 
Forster, J.F., and Horne, J.C., 2005, The interpretation of fluids and pressures in determining conventional and unconventional gas resources in the Rocky Mountain region, Chapter 7, in Bishop, M.G., Cumella, S.P., Robinson, J.W., and Silverman, M.R., eds., Gas in low permeability reservoirs of the Rocky Mountain region: Rocky Mountain Association of Geologists 2005 Guidebook CD, Denver, Colorado, p. 187-210.

IHS Energy, 2009, U.S. Production and Well Data: Englewood, Colo., database available from IHS Energy, 15 Inverness Way East, D205, Englewood, Colo. 80112, U.S.A.

Johnson, R.C., Finn, T.M., and Roberts, L.N.R., 2005, The Mesaverde total petroleum system, Southwestern Wyoming Province, Chapter 8 of Petroleum systems and geologic assessment of oil and gas in the Southwestern Wyoming Province, Wyoming, Colorado, and Utah: U.S. Geological Survey Digital Data Series DDS-69-D, 38 p.

Keighin, C.W., Law, B.E., and Pollastro, R.M., 1989, Petrology and reservoir characteristics of the Almond Formation, Greater Green River Basin, Wyoming, in Coalson, E.B., and others, eds., Petrogenesis and petrophysics of selected sandstone reservoirs of the Rocky Mountain region: Rocky Mountain Association of Geologists, Denver, Colorado, p. 281-298.

Kovach, P.L., Caldaro-Baird, J.L., and Wynne, P.J., 2001, Stagecoach Draw Field: gas production from the westernmost marine-influenced deposits of the Lewis Seaway transgression into southwestern Wyoming, Chapter 10, in Anderson, D. ed., Gas in the Rockies: Rocky Mountain Association of Geologists, Denver, Colorado, p. 125-144.

Law, B., 1984, Relationships of source-rock, thermal maturity, and overpressuring to gas generation and occurrence in lowpermeability Upper Cretaceous and Lower Tertiary rocks, Greater Green River Basin, Wyoming, Colorado, and Utah, in Woodward, J., Meissner, F.F., and Clayton, J.L., eds., Hydrocarbon source rocks of the greater Rocky Mountain region: Rocky Mountain Association of Geologists, p. 469-490.

Law, B., and Johnson, R.C., 1989, Structural and stratigraphic framework of the Pinedale Anticline, Wyoming, and the Multiwell Experiment Site, Colorado, Chapter B in Law, B.E., and Spencer, C.W., eds., Geology of tight gas reservoirs in the Pinedale Anticline area, Wyoming, and at the Multiwell Experiment Site, Colorado: U.S. Geological Survey Bulletin 1886, 11 p.

McCain, W.D., Jr., 1990, The properties of petroleum fluids: Tulsa, Okla., Pennwell Books, 548 p.
McPeek, L.A., 1981, Eastern Green River basin: a developing giant gas supply from deep, overpressured Upper Cretaceous sandstones, American Association of Petroleum Geologists Bulletin, v. 65, p. 1078-1098.

Martinsen, R.S., and Christensen, G., 1992, A stratigraphic and environmental study of the Almond Formation, Mesaverde Group, Greater Green River Basin, Wyoming, in Mullen, C.E., ed., Rediscover the Rockies: Rocky Mountain Association of Geologists Forty-Third Field Conference Guidebook, p. 171-190.

Martinsen, R.S., 1998, Compartmentalization of sandstone reservoirs due to syndepositional faulting, Almond Formation, Washakie Basin, Wyoming, in Slatt, R.M., ed., Compartmentalized reservoirs in Rocky Mountain Basins: Rocky Mountain Association of Geologists Symposium, p. 71-98.

Nelson, P.H., Trainor, P.K., and Finn, T.M., 2009, Gas, oil, and water production in the Wind River Basin, Wyoming: U.S. Geological Survey Scientific Investigations Report 2008-5225, 33 p.

Nelson, P.H., and Hoffman, E.L., 2009, Gas, oil, and water production from the Wasatch Formation, Greater Natural Buttes Field, Uinta Basin, Utah: U.S. Geological Survey Open-File Report 2009-1049, 19 p.

Quint, E., Singh, M., Huckabee, P., Brown, D., Brake, C.B., Bickley, J. and Johnston, B., 2006, 4D pressure pilot to steer well spacing in tight gas, Society Petroleum Engineers paper 102745, Annual Technical Conference and Exhibition, San Antonio, Texas, 14 p.

Roberts, L.N.R., Lewan, M.D., and Finn, T.M., 2005, Burial history, thermal maturity, and oil and gas generation history of petroleum systems in the Southwestern Wyoming Province, Wyoming, Colorado, and Utah, Chapter 3 of Petroleum systems and geologic assessment of oil and gas in the Southwestern Wyoming Province, Wyoming, Colorado, and Utah: U.S. Geological Survey Digital Data Series DDS-69-D, 25 p.

Shanley, K.W., 2004, Fluvial reservoir description for a giant, low-permeability gas field: Jonah Field, Green River Basin, Wyoming, U.S.A., Chapter 10, in Robinson, J.W., and Shanley, K.W., eds., Jonah Field: case study of a tightgas fluvial reservoir, American Association of Petroleum Geologists Studies in Geology 52: Rocky Mountain Association of Geologists 2004 Guidebook, p. 37-59.

Wyoming Oil and Gas Conservation Commission, 2009, Accessed 05/01/2009—06/30/09 at http://wogcc.state. wy.us/. 